\title{
ICT Uptake and Technology Linkages in Rural Africa
}

\author{
Juseuk Kim ${ }^{1, *}$
}

${ }^{1}$ Joongbu University, Korea

*Correspondence: Joongbu University, Korea. Tel: 82-10-2953-0653. E-mail: juseuk.kim@gmail.com

Received: June 4, 2017 Accepted: August 24, 2017 Published: September 22, 2017

doi:10.5296/ije.v9i3.11901ＵRL: https://doi.org/10.5296/ije.v9i3.11901

\begin{abstract}
This report focuses on how quickly and creatively electronic communication is spreading and transforming rural areas in Africa and, particularly, two selected communities in Zambia as case studies. The report also shows ways in which communities are adapting information and communication technologies (ICTs). And this research is interested in studying how quickly electronic communication is spreading and transforming rural areas in Africa and, in particular, the Republic of Zambia. The impact of social networks is being used in dynamic, creative ways to not only spread business opportunities but to energize economies and society. They want to gather community and household information to understand the many ways communities are adapting these technologies. Their methods of adoption and adaptation of technologies do not resemble high-tech societies where governments support massive infrastructure projects. For example, highly creative uses of low-tech cell phones are energizing commerce and spawning new ways of building creative solutions, making African countries some of the fastest growing economies in the world today.
\end{abstract}

Keywords: Information and Communication Technologies, Smart Phone, Cell Phone, Libala Community, Chongwe Community, Household Surveys 


\section{Introduction}

In the creative economy, it is one of the critical issues how to use technologies. Recent works and theories coming out of multilateral organizations, such as the World Bank and the Organization for Economic Cooperation and Development (OECD), indicate that increasingly the most important connections are between networks of emerging industries and social entrepreneurs, along with their shared ideas and innovations. These multilateral agencies emphasize the essential benefits offered by these linkages. They are seen to serve as engines of growth both for emerging economies, and as valuable resources for wealthier countries.

This report focuses on how quickly and creatively electronic communication is spreading and transforming rural areas in Africa and, in particular, the Republic of Zambia. Because of costs and infrastructure, African societies are not using and adopting technologies the same ways that high-tech societies use technologies. Their methods do not resemble high-tech societies where governments support massive infrastructure projects. For example, highly creative uses of low-tech cell phones are energizing commerce and spawning new ways of building creative solutions, making African countries some of the fastest growing economies in the world today.

The report also covers how technologies impact on the community welfare of Zambian communities. Community welfare is likely to be defined a community condition that agrees to the community's value (Jonassen, 1960). For instance, those terms such as healthy life, happiness, good housing condition can be the value that communities may pursue. The impact of social networks is being used in dynamic, creative ways to not only spread business opportunities but to energize economies and society.

Throughout our research which we gathered communities and households information in Zambia, the report is likely to show how to understand the many ways communities are adapting these technologies.

\section{Growing importance of Innovation, Creativity and Knowledge in ODA}

Ever since the World Bank highlighted the role of knowledge in development in its 1999 annual development report, entitled "Knowledge for Development," knowledge has been considered a major component of development (World Bank, 1998). But the concept was advanced earlier by Paul Romer (1993) at a World Bank conference in which he described his theory of knowledge as an economic unit in international development. He argued that countries capable of creative new ideas were making more rapid economic progress by using their resources in innovative and creative ways (Romer, 1993). His original theory of "endogenous technological change" is more commonly known now as "new growth theory" (Cortight, 2001).

Lundvall, Joseph, Chaminade and Vang (2011) talk about the importance of this innovation in developing countries. A primary way that innovation has been adding to productivity has 
been through the adoption of technology through social entrepreneurship. Gardner and colleagues (2007) discuss the innovative ways that technology is being put to use in the health field in Africa. The spread of technology in Africa is also being applied to other disciplinary fields and creative new approaches in research.

\section{Emergence of Technology in Africa}

During the past couple of years, the spread of communication technology increased significantly in Africa. A very prominent example is the expansion of the network of new fiber optic cables around the African continent (Song, n.d.), making the access to global knowledge and the exchange of knowledge easier. Because of this extension, the cost for Internet has been lowered significantly (Esterhuizen, 2012; Ogunlesi, 2012) and the number of Internet users has increased.

The use of technology is also creative. A Cornell business school graduate and native of Ethiopia, went home to solve a problem of market imperfections using technology. By integrating very low level cell phone use in rural areas, with simple networks in the main city, she linked coffee farmers to global markets. Coffee production flourished in the communities. In turn, the incomes of coffee producers in rural areas rose substantially as did the quality and quantity of their coffee production. But their use of communication technology was found to be quite different from that of Korea or the U.S. (Petty, 2010).

Similarly, Kenya has discovered a creative way of using cell phones in its banking industry. Slightly more than one-half of all personal money transactions in Kenya are done through phone transfers Unlike Korea where money is transferred between accounts, in Kenya the use of phones involves direct fund transfers by mobile phone companies using low-level technology phones (Porteous, 2006). These examples of new business methods follow a model referred to as social entrepreneurship which is particularly successful in Africa and is technology-based. Alex Nicholls has written two books on the market potential of this creative approach (Nicholls \& Murdock, 2012; Nicholls, 2006).

\section{Literature Review}

\subsection{Technology Diffusion}

It is not common in practice to adopt a new idea immediately even when it has an apparent advantage over an existing product or process. It takes time to be diffused among members of a society (Rogers, 2003). According to Scherer(1980), diffusion is the final stage of an innovation process, following the invention, development, and production stages. Without the last stage, adaptation, the innovation process is incomplete since new technologies only can have economic impact when they are used widely among members of a society.

There is a variety of definitions of diffusion. The definition proposed by Everett M.Rogers is referenced mostly among diffusion researchers: "Diffusion of innovation is the process in 
which an innovation is communicated through certain channels over time among the members of social system (Rogers 2003)". According to Rogers(2003) definition the process of diffusion consists of four elements: innovation, communication channels, time and social system. Every diffusion study can identify these elements.

In this diffusion process, innovation stands for any idea, product or practice that is perceived an new by members of society system. As most of the new idea related to technology, innovation and technology are synonyms. In this report they have exactly same meaning. The communication channel is the means of getting a message from one individual to another. Mass media channels such as television, radio, newspaper are the regularly used communication channels for innovation diffusion. Time refers to a measurement of 1) an innovation-diffusion process by which an individual passes from first knowledge of an innovation through its adoption or rejection, 2) innovativeness of an adoption (early or late adoption) and 3) an innovation rate adoption in a system (number of adopters at time T). The social system is a set of interrelated units that are engaged in joint problem solving to accomplish a common goal. The social system consists of individuals, organizations, or agencies that are potential adopters of the innovation.

In a narrow and literal sense, technology diffusion refers to the adoption of a new technique by the firms in an industry after the technique has been introduced (Shen, 1973). Innovation diffusion is a well-defined process proven empirically by many researchers using number of various models that have been developed. Naturally, the number of adoptions of a new idea grows slowly at the start. Then during the middle stage the growth rate increases and peaks, and in the final stage a decreased rate of growth is exhibited as full equilibrium demand is reached (Kumar 1992). The main focus of many studies related to technology diffusion is the time dependent characteristics of the innovation diffusion process.

We cannot assume all ICT devices and services are equivalent units of analysis. While some innovations such as cell phones and Internet diffuse widely in only a few years, other new ideas like fixed telephone lines and laptop computer in Africa take decades to diffuse. Rogers defined the characteristics of innovation that explain their different rates of adoption.

\subsection{ICT in Africa}

Innovation and adaptation process of mobile device is one of the most important topic addressed by lots of researchers in different fields, who apply a variety models and analyze factors affecting it. This report focuses on roles of information and communication technology in Africa region rather than innovation process itself. Especially, this report analyzes how the diffusion of ICT device and service leads to growths of welfare and economy in Africa.

The role of ICT in Africa countries needs to be investigated more since many countries still have poor or closed ICT market especially in the fixed and mobile telephoning sector. Though, in the last decade ICT sector's share of investment activity and of the economy has rapidly increased in the rest of the world (Wang E. H. 1999). Another study about United States showed that the use of ICT and production had been the main factors behind US 
economic performance in the 1990s (Jalava and Pohjola, 2002). In the case of Finland, Jalava and Pohjola (2002) found that the contribution of ICT in production increased from $0.3 \%$ to $0.7 \%$ for the period between early $1990 \mathrm{~s}$ and the late $1990 \mathrm{~s}$. Another interesting study about ICT and economic growth in the United Kingdom made by Bakhshi and Larsen(2002) argues that an increase in ROI in ICT will raise both the deprecation rate and the expenditure, while the continuous ICT-specific TFP growth rate will raise the investment expenditure share of GDP and reduce aggregated deprecation rate.

Though, there is still shortage in evidence of the ICT contribution in the economic growth of Africa countries. For instance, a recent study showed that the significance of ICT contribution to economic growth is only "in many developed countries and newly industrialized economies; but not in developing countries like many regions in Africa".

Currently, analyzing cases of developing countries and developed countries, the two main sources of fast national development growth are Foreign Direct Investment (FDI), and Information Communications Technology (ICT) as a way of eliminating financial obstacles while increasing productivity. However as a result of a complex political, religious and cultural region, the Middle East and North Africa (AMENA) region is lagging behind most regions in both FDI and ICT development. For the last 20 years, FDI inflow to the MENA region is only $0.8 \%$ of total FDI inflow toward developing countries.

Even though many factors are affecting economic growth, the ICT role is becoming a major source for the development especially for developing countries, examples of this development could be seen clearly from the Indian case. India spread its ICT infrastructure and used successfully ICT tools for the development of rural sector through regulation reforms especially privatization, building public information kiosks, and public-private partnership, despite of many issues including low literacy rate connectivity and infrastructure obstacles.

Hence, substantial academic and practical attention toward this relationship is increasing in the last ten years, mainly because of the recent overall idea that Information and Communication Technology (ICT) playing role in the economic development is increasing rapidly after the fast development of Internet and Mobile Telecommunication networks. Yet, this kind of study is rare when it comes to most Africa countries. This might be because of the difficulties of estimating the directional relationship between ICT and economic development especially in developing countries, and the lack of reliable data and resources to conduct such studies. Nowadays, the investment of ICT in that region is increasing rapidly as the result of globalization, young leaders' awareness, political and social pressures locally and globally. Therefore, both the existing and the expected future of ICT in Africa regions are needed to be analyzed more since many countries still have poor or closed ICT market especially in the fixed and wireless Internet.

\section{Methodology}

This study aimed at fully understanding the different ways local communities in Zambia are 
adapting the Information and Communication Technologies (ITCs). For this purpose, a mixed method approach was used in this study: a quantitative household survey and qualitative interviews were designed to track and gather community-level and household-level data. The focus was on how communities and individuals are using, and have recently changed their use of technologies.

\subsection{The Approach of This Research}

While the potential of technology in Africa is evident from this discussion, to fully understand its potential in African development requires investigating how communities adapt to and adopt technology. There is a keen understanding of the adoption and adaptation of technology tools by persons who are highly educated and have easy access to the crucial infrastructure. It can be assumed that persons from the most remote and poorest communities will remain somewhat marginalized for a time. And yet, many communities are thriving in rural areas with limited access to technology networks. Questions to be explored include: is their adoption of technology linked to their social networks, economy, education and perceptions of change and possibilities? What technologies have they adopted recently and why? Who were the initial adopters? Who passed along these skills and ideas, and to whom? What have been their goals, hopes and ideas as they adopted this new technology? What other new possibilities (or problems) have opened up for local individuals and communities?

\subsection{Household Surveys}

A household survey is being drafted using a previous household survey and methodology that is conducted every ten years with funding by The World Bank or major bi-lateral donor. Zambia's last household survey was in 2007 and covered an estimated 13,500 people in a representative sample. The survey was nearly 20 pages in length (Ministry of Health, 2009). In order to track dynamic changes and responses to global forces, a much smaller survey is envisioned that can be done more efficiently and with greater frequency.

Most data in poor countries has followed the design of census surveys in wealthier countries that are collected every ten years or longer. Household surveys in poor countries tend to be extensive and costly, involving large amounts of information taken on every member of a household (Deaton, 1997). Although much information can be gleaned from these surveys, it is generally agreed that the methodology is flawed - albeit the best possible for the money and methodology (Groves \& Couper, 1998; Guenard \& Mesplé-Somps, 2010).

\subsection{Sampling Frame}

The primary unit of sampling in this survey was households (HHs) in two local communities, namely, Libala and Chongwe. These were randomly selected in Lusaka Province of Zambia. Libala is a middle income community while Chongwe is a low income one. A total of one hundred (100) households were randomly selected from each community. In order to derive the sample size of the household survey, the research had an appreciation of the total population of the two communities by collecting the actual statistics from the Central Statistical Office (CSO) of Zambia. Each household had an average of five (5) people. A 
questionnaire was used to gather data from each household.

\section{Research Results}

\subsection{Presentation and Discussion of Quantitative Findings}

\subsubsection{Basic technology utilization pattern of communities}

Job composition of technical users was as follows. Student was the most popular job composition for technical users followed by worker, Unemployed, Business, House keeper. In addition, the portion of the Worker and Business in Libala community was relatively higher than Chongwe community, and the portion of Umemployed and House keeper in Chongwe community was relatively higher in than Libala community. In general, respondents in Libala community were exposed to more social activities than Chongwe community.

Table 1. Occupation of Technical Users

\begin{tabular}{|c|c|c|c|c|c|c|c|}
\hline \multirow{2}{*}{ Occupation } & \multicolumn{3}{|c|}{ Chongwe } & \multicolumn{3}{|c|}{ Libala } & \multirow{2}{*}{ Total } \\
\hline & Female & Male & Sum & Female & Male & Sum & \\
\hline ACCOUNTANT & & 2 & 2 & & 1 & 1 & 3 \\
\hline $\begin{array}{l}\text { AGRICULTURAL } \\
\text { ENGINEER }\end{array}$ & & 1 & 1 & & & & 1 \\
\hline BAR TENDER & 1 & 1 & 2 & & & & 2 \\
\hline BUSINESS & 2 & 3 & 5 & 10 & 3 & 13 & 18 \\
\hline CHEF & 1 & & 1 & & & & 1 \\
\hline CIVIL SERVANT & & & & 1 & & 1 & 1 \\
\hline COUNCIL OFFICER & & 1 & 1 & & & & 1 \\
\hline COUNCIL WORKER & 1 & & 1 & & & & 1 \\
\hline FARMER & & 1 & 1 & & & & 1 \\
\hline HEALTH PRACTITIONER & & & & & 1 & 1 & 1 \\
\hline HOTELIAN & & & & 1 & & 1 & 1 \\
\hline HOUSE KEEPER & 10 & & 10 & 3 & & 3 & 13 \\
\hline LOAFER & 2 & 1 & 3 & 4 & & 4 & 7 \\
\hline LODGE MANAGER & & & & 1 & & 1 & 1 \\
\hline MAID & 4 & & 4 & 1 & & 1 & 5 \\
\hline PASTOR & & 1 & 1 & & & & 1 \\
\hline PHARMACIST & 1 & & 1 & & & & 1 \\
\hline RETIRED & 2 & & 2 & 5 & 1 & 6 & 8 \\
\hline SCHOLAR & 1 & 2 & 3 & & & & 3 \\
\hline SCHOOL LEAVER & 1 & & 1 & 2 & 2 & 4 & 5 \\
\hline SECRETARY & & & & 1 & & 1 & 1 \\
\hline SECURITY GUARD & & 1 & 1 & & & & 1 \\
\hline STUDENT & 9 & 10 & 19 & 4 & 12 & 16 & 35 \\
\hline TEACHER & 3 & 3 & 6 & 3 & & 3 & 9 \\
\hline TRAVEL AGENT & 1 & & 1 & & & & 1 \\
\hline UNEMPLOYED & 11 & 8 & 19 & & & & 19 \\
\hline VILLAGE HEADMAN & & 1 & 1 & & & & 1 \\
\hline WORKER & 6 & 7 & 13 & 12 & 10 & 22 & 35 \\
\hline Total & 56 & 43 & 99 & 48 & 30 & 78 & 177 \\
\hline
\end{tabular}


First of all, cell phone was the most popular device for technical users in both of Libala and Chongewe communities. In particular, the utilization proportion of the cell phone was higher in Chongewe than Libala. And it is fairly common that Cell phone users also use a smart phone at the same time. Although the electronic market was not formed in Chongewe which is the lowest income in the Zambia, there was a mobile market.

Additionally, the utilization ratio of smart phones and lap top was similar between Libala and Chongwe communities, but technical users in Libala slightly more used smart phones and lap top than Chongwe. Household used mainly desktop computer rather than laptop.

Table 2. Utilization Pattern of Technology of Technology Users by Communities

\begin{tabular}{|c|c|c|c|c|c|c|c|c|c|c|c|c|}
\hline \multirow{3}{*}{$\begin{array}{c}\text { Users } \\
\text { cell phone }\end{array}$} & \multicolumn{4}{|c|}{$\begin{array}{c}\text { Chongwe community } \\
\text { (100 persons) }\end{array}$} & \multicolumn{4}{|c|}{$\begin{array}{l}\text { Libala community } \\
\text { (97 persons) }\end{array}$} & \multicolumn{4}{|c|}{$\begin{array}{c}\text { Communities Total } \\
\text { (197 persons) }\end{array}$} \\
\hline & \multicolumn{2}{|c|}{ NO } & \multicolumn{2}{|c|}{ YES } & \multicolumn{2}{|c|}{ NO } & \multicolumn{2}{|c|}{ YES } & \multicolumn{2}{|c|}{ NO } & \multicolumn{2}{|c|}{ YES } \\
\hline & 10 & $10 \%$ & 90 & $90 \%$ & 31 & $32 \%$ & 66 & $68 \%$ & 41 & $21 \%$ & 156 & $79 \%$ \\
\hline smartphone & 69 & $69 \%$ & 31 & $31 \%$ & 61 & $63 \%$ & 36 & $37 \%$ & 130 & $66 \%$ & 67 & $34 \%$ \\
\hline $\begin{array}{c}\text { desktop } \\
\text { computer }\end{array}$ & 95 & $95 \%$ & 5 & $5 \%$ & 95 & $98 \%$ & 2 & $2 \%$ & 190 & $96 \%$ & 7 & $4 \%$ \\
\hline $\begin{array}{c}\text { laptop } \\
\text { computer }\end{array}$ & 79 & $79 \%$ & 21 & $21 \%$ & 74 & $76 \%$ & 23 & $24 \%$ & 153 & $78 \%$ & 44 & $22 \%$ \\
\hline $\begin{array}{c}\text { other } \\
\text { technology }\end{array}$ & 99 & $99 \%$ & 1 & $1 \%$ & 94 & $97 \%$ & 3 & $3 \%$ & 193 & $98 \%$ & 4 & $2 \%$ \\
\hline
\end{tabular}

The utilization pattern was not different significantly following communities and gender. Only the utilization pattern of male technology users was slightly higher in both of Labala and Chongwe communities. Specially, $93 \%$ of female used Cell phone in Chongwe community while only $68 \%$ of female used Cell phone in Libala community. And there was different pattern for male technical user for Cell phone between communities. $86 \%$ of male used Cell phone in Chongwe while only $68 \%$ in Libala.

Table 3. Technology Users by Gender

\begin{tabular}{|c|c|c|c|c|c|c|c|c|c|c|c|c|c|c|}
\hline \multirow{3}{*}{$\begin{array}{c}\text { Users } \\
\text { cell phone }\end{array}$} & \multicolumn{6}{|c|}{ Chongwe } & \multicolumn{6}{|c|}{ Libala } & \multirow{2}{*}{\multicolumn{2}{|c|}{ Total }} \\
\hline & \multicolumn{2}{|c|}{ FEMALE } & \multicolumn{2}{|c|}{ MALE } & \multicolumn{2}{|c|}{ Sum } & \multicolumn{2}{|c|}{ FEMALE } & \multicolumn{2}{|c|}{ MALE } & \multicolumn{2}{|c|}{ Sum } & & \\
\hline & 52 & $93 \%$ & 38 & $86 \%$ & 90 & $90 \%$ & 38 & $68 \%$ & 28 & $68 \%$ & 66 & $68 \%$ & 156 & $79 \%$ \\
\hline smartphone & 16 & $29 \%$ & 15 & $34 \%$ & 31 & $31 \%$ & 20 & $36 \%$ & 16 & $39 \%$ & 36 & $37 \%$ & 67 & $34 \%$ \\
\hline $\begin{array}{c}\text { desktop } \\
\text { computer }\end{array}$ & 1 & $2 \%$ & 4 & $9 \%$ & 5 & $5 \%$ & 0 & $0 \%$ & 2 & $5 \%$ & 2 & $2 \%$ & 7 & $4 \%$ \\
\hline $\begin{array}{c}\text { laptop } \\
\text { computer }\end{array}$ & 10 & $18 \%$ & 11 & $25 \%$ & 21 & $21 \%$ & 12 & $21 \%$ & 11 & $27 \%$ & 23 & $24 \%$ & 44 & $22 \%$ \\
\hline Total & 56 & & 44 & & 100 & & 56 & & 41 & & 97 & & 197 & \\
\hline
\end{tabular}




\section{I Macrothink}

It is important to find out the utilization purpose of smart phones and laptops, because they can make ubiquitous environment using internet and network. There was difference of purpose using Smart phone between communities. Libala technical users showed diverse range of purposes for using smart phone than Chongwe.

In Chongwe community, more than $30 \%$ of technical user used smart phone for purposes of Talking, Music, Internet, Social network, Camera in order, and more than 50\% of technical user used smart phone for purposes of Talking, Music. In Libala community, more than 30\% of technical user used smart phone for purposes of Talking, Internet, Social network, Music, Camera, E-mail, Calculator, Dictionary, Schedule/Calendar in order, and more than $50 \%$ of technical user used smart phone for purposes of Talking, Internet, Social network, Music, Camera.

Overall purpose for the smartphone utilization was relatively more concentrated in Chongwe than Libala. However, 23\% technical users in Chongwe community used Smartphone for the purpose of game, while $11 \%$ for technical user in Libala community.

Table 4. Utilization Purpose of Smartphone

\begin{tabular}{|c|c|c|c|c|c|c|c|c|c|c|c|}
\hline \multirow{2}{*}{$\begin{array}{l}\text { Smartphone } \\
\text { purpose }\end{array}$} & \multicolumn{4}{|c|}{ Chongwe } & \multirow{3}{*}{$\begin{array}{c}\text { Chongwe } \\
\text { Total }\end{array}$} & \multicolumn{4}{|c|}{ Libala } & \multirow{3}{*}{$\begin{array}{c}\text { Libala } \\
\text { Total }\end{array}$} & \multirow{3}{*}{$\begin{array}{c}\begin{array}{c}\text { Community } \\
\text { Total }\end{array} \\
67\end{array}$} \\
\hline & \multicolumn{2}{|c|}{ No } & \multicolumn{2}{|c|}{ Yes } & & \multicolumn{2}{|c|}{ No } & \multicolumn{2}{|c|}{ yes } & & \\
\hline Talking & 5 & $16 \%$ & 26 & $84 \%$ & & 2 & $6 \%$ & 34 & $94 \%$ & & \\
\hline Calculator & 27 & $87 \%$ & 4 & $13 \%$ & 31 & 23 & $64 \%$ & 13 & $36 \%$ & 36 & 67 \\
\hline Camera & 21 & $68 \%$ & 10 & $32 \%$ & 31 & 17 & $47 \%$ & 19 & $53 \%$ & 36 & 67 \\
\hline Dictionary & 28 & $90 \%$ & 3 & $10 \%$ & 31 & 25 & $69 \%$ & 11 & $31 \%$ & 36 & 67 \\
\hline Internet & 16 & $52 \%$ & 15 & $48 \%$ & 31 & 6 & $17 \%$ & 30 & $83 \%$ & 36 & 67 \\
\hline E-mail & 26 & $84 \%$ & 5 & $16 \%$ & 31 & 20 & $56 \%$ & 16 & $44 \%$ & 36 & 67 \\
\hline Games & 24 & $77 \%$ & 7 & $23 \%$ & 31 & 32 & $89 \%$ & 4 & $11 \%$ & 36 & 67 \\
\hline Radio/TV & 27 & $87 \%$ & 4 & $13 \%$ & 31 & 32 & $89 \%$ & 4 & $11 \%$ & 36 & 67 \\
\hline Music (MP3) & 15 & $48 \%$ & 16 & $52 \%$ & 31 & 16 & $44 \%$ & 20 & $56 \%$ & 36 & 67 \\
\hline Schedule / Calendar & 27 & $87 \%$ & 4 & $13 \%$ & 31 & 29 & $81 \%$ & 7 & $19 \%$ & 36 & 67 \\
\hline Social Network & 18 & $58 \%$ & 13 & $42 \%$ & 31 & 9 & $25 \%$ & 27 & $75 \%$ & 36 & 67 \\
\hline Video & 26 & $84 \%$ & 5 & $16 \%$ & 31 & 33 & $92 \%$ & 3 & $8 \%$ & 36 & 67 \\
\hline Web searching & 26 & $84 \%$ & 5 & $16 \%$ & 31 & 21 & $58 \%$ & 15 & $42 \%$ & 36 & 67 \\
\hline Other & 28 & $90 \%$ & 3 & $10 \%$ & 31 & 34 & $94 \%$ & 2 & $6 \%$ & 36 & 67 \\
\hline
\end{tabular}

In Chongwe community, more than $30 \%$ of technical user used laptop for purposes of Music, Internet, Education, Game in order, and more than 50\% of technical user used laptop for purposes of Music. In Libala community, more than $30 \%$ of technical user used laptop for purposes of Internet, Email, Education, Social Network, Music in order, and more than 50\% of technical user used laptop for purposes of Internet, Email, Education, Social Network.

Specially, more than $50 \%$ of Libala technical users showed diverse range of purposes for 
using laptop while Chongwe was not. Only the Music was the purpose which is used more than $50 \%$ of technical users in Chongwe. However, 33\% technical users in Chongwe community used laptop for the purpose of game, while only $4 \%$ for technical user in Libala community.

In summary, technical users in Chongwe community has limited purpose using a smartphone and laptop rather than Libala community. And dissemination and utilization situation of ICT showed quite different pattern following communities in Zambia.

Table 5. Utilization Purpose of Laptop

\begin{tabular}{|c|c|c|c|c|c|c|c|c|c|c|c|}
\hline \multirow[t]{2}{*}{ Laptop Purpose } & \multicolumn{4}{|c|}{ Chongwe } & \multirow{2}{*}{$\begin{array}{c}\text { Chongwe } \\
\text { Total } \\
\end{array}$} & \multicolumn{4}{|c|}{ Libala } & \multirow{3}{*}{$\begin{array}{c}\text { Libala } \\
\text { Total } \\
23\end{array}$} & \multirow{2}{*}{$\frac{\text { Community }}{\text { Total }}$} \\
\hline & & 10 & & & & & Jo & & & & \\
\hline Business & 15 & $71 \%$ & 6 & $29 \%$ & 21 & 15 & $65 \%$ & 8 & $35 \%$ & & 44 \\
\hline Education & 14 & $67 \%$ & 7 & $33 \%$ & 21 & 10 & $43 \%$ & 13 & $57 \%$ & 23 & 44 \\
\hline Email & 17 & $81 \%$ & 4 & $19 \%$ & 21 & 9 & $39 \%$ & 14 & $61 \%$ & 23 & 44 \\
\hline Internet & 13 & $62 \%$ & 8 & $38 \%$ & 21 & 6 & $26 \%$ & 17 & $74 \%$ & 23 & 44 \\
\hline $\begin{array}{l}\text { Social Network } \\
\text { (facebook) }\end{array}$ & 16 & $76 \%$ & 5 & $24 \%$ & 21 & 11 & $48 \%$ & 12 & $52 \%$ & 23 & 44 \\
\hline Video & 13 & $62 \%$ & 8 & $38 \%$ & 21 & 21 & $91 \%$ & 2 & $9 \%$ & 23 & 44 \\
\hline Phone/ Skype & 19 & $90 \%$ & 2 & $10 \%$ & 21 & 20 & $87 \%$ & 3 & $13 \%$ & 23 & 44 \\
\hline Radio/TV & 21 & $100 \%$ & 0 & $0 \%$ & 21 & 23 & $100 \%$ & 0 & $0 \%$ & 23 & 44 \\
\hline Music (MP3) & 10 & $48 \%$ & 11 & $52 \%$ & 21 & 13 & $57 \%$ & 10 & $43 \%$ & 23 & 44 \\
\hline $\begin{array}{l}\text { Schedule / } \\
\text { Calendar }\end{array}$ & 20 & $95 \%$ & 1 & $5 \%$ & 21 & 22 & $96 \%$ & 1 & $4 \%$ & 23 & 44 \\
\hline Games & 14 & $67 \%$ & 7 & $33 \%$ & 21 & 22 & $96 \%$ & 1 & $4 \%$ & 23 & 44 \\
\hline Organizing info. & 17 & $81 \%$ & 4 & $19 \%$ & 21 & 17 & $74 \%$ & 6 & $26 \%$ & 23 & 44 \\
\hline Other & 20 & $95 \%$ & 1 & $5 \%$ & 21 & 23 & $100 \%$ & 0 & $0 \%$ & 23 & 44 \\
\hline
\end{tabular}

\subsection{ICT Uptake Pattern of Communities}

53 technical users of smart phone responded about useing period. Period of 6-12 months of use was $25 \%$, and 1-2 years of use was the highest with the $28 \%$. Specially, more than half of users $(55 \%)$ started to use the smartphone in 1 year. This shows a rapid increase of Smartphone usage pattern recently.

Table 6. How Long Have You Used or Owned Smartphone?

\begin{tabular}{ccccccc}
\hline $\begin{array}{c}\text { How long have you used or } \\
\text { owned Smartphone? }\end{array}$ & \multicolumn{2}{c}{ Chongwe } & \multicolumn{2}{c}{ Libala } & \multicolumn{2}{c}{ Total } \\
\hline$<3$ months & 6 & $29 \%$ & 4 & $13 \%$ & 10 & $19 \%$ \\
$3-6$ months & 4 & $19 \%$ & 2 & $6 \%$ & 6 & $11 \%$ \\
6-12 months & 2 & $10 \%$ & 11 & $34 \%$ & 13 & $25 \%$ \\
1-2 years & 3 & $14 \%$ & 12 & $38 \%$ & 15 & $28 \%$ \\
$2-3$ years & 1 & $5 \%$ & 3 & $9 \%$ & 4 & $8 \%$ \\
3-4 years & 4 & $19 \%$ & 0 & $0 \%$ & 4 & $8 \%$ \\
more than 4 yrs & 1 & $5 \%$ & 0 & $0 \%$ & 1 & $2 \%$ \\
Total & $\mathbf{2 1}$ & & $\mathbf{3 2}$ & & $\mathbf{5 3}$ & \\
\hline
\end{tabular}


39 technical users of computer responded about usage period. But only 13\% (5 peoples) started to use computer in 1 year. This shows a slow increase of computer usage pattern than smartphone.

Table 7. How long Have You Used or Owned Computer?

\begin{tabular}{ccccccc}
\hline $\begin{array}{c}\text { How long have you } \\
\text { used or owned computer? }\end{array}$ & \multicolumn{2}{l}{ Chongwe } & \multicolumn{2}{c}{ Libala } & \multicolumn{2}{c}{ Total } \\
\hline$<3$ months & 0 & $0 \%$ & 0 & $0 \%$ & 0 & $0 \%$ \\
$3-6$ months & 0 & $0 \%$ & 0 & $0 \%$ & 0 & $0 \%$ \\
6-12 months & 3 & $19 \%$ & 2 & $9 \%$ & 5 & $13 \%$ \\
1-2 years & 1 & $6 \%$ & 10 & $43 \%$ & 11 & $28 \%$ \\
2-3 years & 5 & $31 \%$ & 7 & $30 \%$ & 12 & $31 \%$ \\
3-4 years & 2 & $13 \%$ & 3 & $13 \%$ & 5 & $13 \%$ \\
more than 4 yrs & 5 & $31 \%$ & 1 & $4 \%$ & 6 & $15 \%$ \\
Total & $\mathbf{1 6}$ & & $\mathbf{2 3}$ & & $\mathbf{3 9}$ & \\
\hline
\end{tabular}

The most using purpose of smartphones were Social Network, Music, Internet in order.

This shows the increase of communication via Smartphone usage and increase of quality of life. But, since the standard deviation has high score for each, this shows that the difference usage or owned period is large depending on people.

Table 8. How Many Minutes Each Week for Smartphone?

\begin{tabular}{|c|c|c|c|c|c|c|c|c|c|}
\hline \multirow{2}{*}{$\begin{array}{c}\text { How many } \\
\text { minutes each } \\
\text { week for } \\
\text { smartphone? }\end{array}$} & \multicolumn{3}{|c|}{ Chongwe } & \multicolumn{3}{|c|}{ Libala } & \multicolumn{3}{|c|}{ Total } \\
\hline & number & average & $\begin{array}{l}\text { standard } \\
\text { deviation }\end{array}$ & number & average & $\begin{array}{l}\text { standard } \\
\text { deviation }\end{array}$ & number & average & $\begin{array}{l}\text { standard } \\
\text { deviation }\end{array}$ \\
\hline Talking & 22 & 200 & 236 & 36 & 380 & 681 & 58 & 311 & 563 \\
\hline Calculator & 4 & 78 & 71 & 12 & 19 & 15 & 16 & 33 & 46 \\
\hline Camera & 9 & 45 & 58 & 20 & 36 & 42 & 29 & 38 & 47 \\
\hline Dictionary & 4 & 47 & 33 & 11 & 31 & 21 & 15 & 34 & 25 \\
\hline Internet & 14 & 188 & 177 & 31 & 784 & 1,034 & 45 & 608 & 914 \\
\hline E-mail & 5 & 175 & 156 & 16 & 79 & 86 & 21 & 102 & 114 \\
\hline Games & 7 & 115 & 117 & 4 & 30 & 19 & 11 & 84 & 103 \\
\hline Radio/TV & 4 & 573 & 647 & 5 & 130 & 129 & 9 & 327 & 494 \\
\hline Music (MP3) & 11 & 649 & 824 & 21 & 956 & 1,515 & 32 & 850 & 1,327 \\
\hline $\begin{array}{l}\text { Schedule / } \\
\text { Calendar }\end{array}$ & 4 & 88 & 123 & 7 & 13 & 8 & 11 & 40 & 83 \\
\hline $\begin{array}{l}\text { Social } \\
\text { Network }\end{array}$ & 13 & 487 & 1,126 & 28 & 1,058 & 1,535 & 41 & 887 & 1,448 \\
\hline Video & 0 & - & - & 4 & 81 & 94 & 6 & 81 & 94 \\
\hline Web searching & 2 & 250 & 50 & 16 & 258 & 367 & 18 & 257 & 346 \\
\hline Other & 2 & 2,110 & 2,090 & 1 & 200 & - & 3 & 1,473 & 1,929 \\
\hline
\end{tabular}




\section{Macrothink}

The most using purpose of laptop was Education, Business, Internet in order. Specially, Libala laptop users used laptop mostly in using education and business. But Chongwe laptop users used laptop mostly in using internet, internet phone and music in order.

Table 9. How Many Minutes Each Week for Laptop?

\begin{tabular}{|c|c|c|c|c|c|c|c|c|c|}
\hline \multirow{2}{*}{$\begin{array}{c}\text { How many } \\
\text { minutes } \\
\text { each week } \\
\text { for } \\
\text { laptop? }\end{array}$} & \multicolumn{3}{|c|}{ Chongwe } & \multicolumn{3}{|c|}{ Libala } & \multicolumn{3}{|c|}{ Total } \\
\hline & number & average & $\begin{array}{c}\text { standard } \\
\text { deviatio } \\
\mathbf{n}\end{array}$ & number & average & $\begin{array}{c}\text { standard } \\
\text { deviatio } \\
\text { n }\end{array}$ & number & average & $\begin{array}{c}\text { standard } \\
\text { deviatio } \\
\text { n }\end{array}$ \\
\hline Business & 6 & 75 & 103 & 8 & 694 & 655 & 14 & 428 & 586 \\
\hline Education & 10 & 233 & 347 & 15 & 1,085 & 2,037 & 25 & 744 & 1,646 \\
\hline Email & 5 & 86 & 69 & 14 & 73 & 59 & 19 & 76 & 62 \\
\hline $\begin{array}{c}\text { Internet } \\
\text { Social }\end{array}$ & 9 & 460 & 428 & 19 & 296 & 205 & 28 & 349 & 306 \\
\hline $\begin{array}{c}\text { Network } \\
\text { (facebook) }\end{array}$ & 6 & 318 & 283 & 13 & 115 & 64 & 19 & 179 & 192 \\
\hline Video & 9 & 284 & 202 & 3 & 27 & 17 & 12 & 220 & 207 \\
\hline $\begin{array}{l}\text { Phone/ } \\
\text { Skype }\end{array}$ & 3 & 310 & 276 & 4 & 44 & 35 & 7 & 158 & 225 \\
\hline Radio/TV & 1 & 120 & - & & & & 1 & 120 & - \\
\hline $\begin{array}{l}\text { Music } \\
\text { (MP3) }\end{array}$ & 11 & 285 & 208 & 11 & 254 & 267 & 22 & 269 & 240 \\
\hline $\begin{array}{l}\text { Schedule / } \\
\text { Calendar }\end{array}$ & 1 & 10 & - & 2 & 40 & 20 & 3 & 30 & 22 \\
\hline Games & 7 & 204 & 224 & 1 & 100 & - & 8 & 191 & 212 \\
\hline $\begin{array}{c}\text { Organizing } \\
\text { info. }\end{array}$ & 2 & 60 & - & 6 & 112 & 72 & 8 & 99 & 66 \\
\hline Other & & & & 1 & 20 & - & 1 & 20 & - \\
\hline
\end{tabular}

Surprisingly most of the technical users responded that the purpose of usage have not been changed periodically. This means that there is lack of training and motivation to use new technology devices. But in overall, the change of purpose of Smartphones users was 1.5 times bigger than regular cell phone users. And the change of purpose of computer users was 2 times bigger than regular cell phone users. in the case of the general mobile smartphones than 1.5 times, the computer almost doubled in the case of using the machine for the first time and the response was different. This is able to infer that the usage purpose of Smartphones and computers can be more and more diverse in future than before. 
Table 10. Are You Using Your Device Differently Now Than You Did Before?

\begin{tabular}{ccccc}
\hline \multirow{2}{*}{ Question } & $\begin{array}{c}\text { What technology do } \\
\text { you use? }\end{array}$ & $\begin{array}{c}\text { Are you using your device differently } \\
\text { now than you did before? }\end{array}$ \\
\hline \multirow{3}{*}{ Chongwe } & Answer & YES & YES \\
& Regular cell phone & 90 & 11 & $12 \%$ \\
& Smartphone & 31 & 3 & $10 \%$ \\
\multirow{3}{*}{ Libala } & Desktop or laptop & 25 & 5 & $20 \%$ \\
& Regular cell phone & $\mathbf{6 6}$ & $\mathbf{1}$ & $\mathbf{2 \%}$ \\
& Smartphone & $\mathbf{3 6}$ & $\mathbf{6}$ & $9 \%$ \\
\multirow{2}{*}{ Total } & Desktop or laptop & 23 & 2 & $8 \%$ \\
& Regular cell phone & 156 & 12 & $13 \%$ \\
& Smartphone & 67 & 9 & $15 \%$ \\
\hline
\end{tabular}

\section{Key Findings and Discussion}

This study mainly aims to build research base of information on how local communities are rapidly adapting technologies in creative and innovative ways to solve problems that improves general health and social welfare, and/or generates personal and business income.

Libala and Chongwe communities were selected for the research. Libala was categorized as a Middle Income and Chongwe was categorized as a Low Income Community respectively following on the Central Statistical Office of Zambia (CSO). 100 household and 200 technical users were surveyed for quantitative data among the communities. And we selected heavy users among technical users for qualitative interview. Each business sectors and institutes of communities were interviewed and three major telecom companies in Zambia were interviewed also. The results of the Quantitative and Qualitative Research provide the following implications:

\subsection{Available Technology Solutions and Services in the Communities}

The following were the technology solutions that were established to be present in both communities: Mobile networks, namely, Global System for Mobile (GSM), an international standard for mobile phones that allows for voice calls, SMS and a little bit of data bundle; General Packet Radio Service (GPRS): Mobile data service available for GSM mobile phones (optimised Network); EDGE (Enhanced Data rates for GSM Evolution) which uses the third generation $(3 \mathrm{G})$ digital network for mobile phones and computers, and LTE (long term evolution) which uses $4 \mathrm{G}$ and was going on for a pilot test in the week beginning 25th August, 2013. The main kind of technology gadgest included Mobile Phones, IPod Tablets, Routers, Laptop Computers, Modems, and Asymmetric Digital Subscriber Lines (ADSL).

A number of services came along with these solutions including voice calling and mailing, text messaging, Internet, Video, Mobile TV, Interactive gaming, Mobile Money Banking, Internet Banking and other value added services which use specific Apps (applications) such 
as mobile offices.

The most utilized of these services were GSM and Internet enabled products and services. These ICTs were used within a social framework that is service and knowledge based (what people need and know determined how much technology they would use and services they would demand for). Thus, this shows that value creation using ICTs in these two communities came by when IT services were provided more than when IT itself was given.

\subsection{Communities’ Technology Utilization Patterns}

The study showed that the pattern of utilization of ICTs in the two sampled communities had no significant differences regardless of the discrepancies in income levels. And their change of ICT usage overtime shared the same pattern. For example, in terms of cellphones, the users moved from basic calling and messaging to functions enabled by internet connectivity as well as special apps in case of those who were using smart phones. For computers, they all began from basic typing in Microsoft word, playing music and videos using media player and watching photos in windows photo viewer. With time, they started acquiring IT sophistry to use spread sheets, publisher, windows movie maker, installing and using different media players, use photoshop and paint, go online and execute other functions and services enabled by internet connectivity.

All these shifts were explained by the same factors, namely, curiosity, fashion and fun, need to access online markets and virtue networks, increasing digital literacy rates, cumulative necessity of using internet for social networking and doing business, and reduction in ICT costs over time but increase in quality of ICT services.

The sources of ICT skills were equally the same, namely, self-taught, social networks both online and offline, and formal institutions. Suffice to say that only $5 \%$ claimed to have acquired ICT skill through formal training and even then, only a small part of the skills were formally learnt.

The total percentage use of the different ICT devices surveyed, that is, basic and smart cellphones, desktop and laptop computers, $57 \%$ of all the respondents were female. This shows that females are more digitally captivated than males.

The study established that the purposes for which these gadgets were used did not differ much based on gender and occupation. The main differences were explained by age and level of education. The young people played more music and videos as well as the internet more for social media. This does not mean the older people did not utilise their gadgets for this. It is the intensity and frequency that was different.

\subsection{Leading Agents in the ICT Sector}

The key agents that advanced the ICT sector in Zambia included the Government Republic of Zambia with its agencies as the regulator, Mobile Telecommunication Companies such as Zamtel, Airtel and MTN, Media Houses like Zambia National Broadcasting Services and The Post Newspaper, and utility Institutions such as financial and security firms, energy and water companies. The main motivation factor for these institutions was cited to be globalization. 
There was more of an external motivation in the ICT sector than local. This was largely explained by the fact that many technologies were not customized to local contexts.

\section{References}

Bakhshi, H., \& Larsen, J. (2005). ICT specific technological progress in the United Kingdom. Journal of Macroeconomics, 27, 645-669. https://doi.org/10.1016/j.jmacro.2004.03.004

Central Statistics Office of Zambia. (2000). Census of Population and Housing. Lusaka: Desktop Publishing Unit, CSO.

Cortight, J. (2001). New Growth Theory, Technology and Learning: A Practitioner's Guide. Impressa, Inc.

Deaton, A. (1997). The Analysis of Household Surveys: A Microeconometric Approach to Development Policy. Baltimore: Johns Hopkins University Press.

Esterhuizen, I. (2012, January 16). Internet growth strong in Africa. Engineering News. Retrieved April 1, 2013, from $\mathrm{http} / /$ www.engineeringnews.co.za/article/internet-growth-strong-in-africa-2012-01-16

Gardner, C. A., Acharya, T., \& Yach, D. (2007). Technological And Social Innovation: A Unifying New Paradigm For Global Health. Health Affairs, 26(4), 1052-1061. https://doi.org/10.1377/hlthaff.26.4.1052

Giovannini, E., Hall, J., Morrone, A., \& Giulia, R. (2009). A framework to measure the progress of societies. Paris: OECD Working Paper. OECD. https://doi.org/10.1787/5km4k7mnrkzw-en

Groves, R., \& Couper, M. (1998). Nonresponse in Household Surveys. New York: Wiley.

Guenard, C., \& Mesplé-Somps, S. (2010). Measuring inequalities: do household surveys paint a realistic picture?, Review of Income and Wealth, 56(3), 519-538. https://doi.org/10.1111/j.1475-4991.2010.00397.x

Jalava, J., \& Pohjola, M. (2002) Economic growth in the new economy: Evidence from advanced economies. Information Economics and Policy, 14, 189-210. https://doi.org/10.1016/s0167-6245(01)00066-X

Lundvall, B.-A., Joseph, K. J., Chaminade, C., \& Vang, J. (2011). Handbook of Innovation Systems and Developing Countries: Building Domestic Capabilities in a Global Setting. Edward Elgar Publishing Inc.

Ministry of Health. (2009). Zambia Demographic and Health Survey 2007. Lusaka, Zambia: Central Statistical Office. https://doi.org/10.1111/j.1728-4465.2010.00247.x

Nicholls, A. (2006). Social Entrepreneurship: New Models of Sustainable Social Change: New Models of Sustainable Social Change. Oxford University Press. 
Nicholls, A., \& Murdock, A. (2012). Social Innovation: Blurring Boundaries to Reconfigure Markets. Palgrave Macmillan.

Ogunlesi, T. (2012, September 14). Seven ways mobile phones have changed lives in Africa. CNN. Retrieved April 1, 2013, from http://www.cnn.com/2012/09/13/world/africa/mobile-phones-change-africa/index.html

Petty, B. (2010, Spring). Ethiopia Commodity Exchange (ECX) as seen by the Communications Consultant. Agriculture for Development, pp. 25-28.

Porteous, D. (2006). The enabling environment for mobile banking in Africa (p. 60). Department f or International Development. Retrieved from http://www.cab.org.in/ICTPortal/Lists/Knowledge\%20Bank/Attachments/14/Enabling\% 20Environment\%20for\%20M-banking\%20-\%20Porteous_16_12_200749.pdf

Rogers, E. (2003). Diffusion of Innovation (5th Ed.). Free Press, New York.

Romer, P. (1993). Two strategies for economic development: using ideas and producing ideas. In Proceedings of the World Bank annual conference on development economics 1992 (pp. 63-92). Washington, D.C.: World Bank. https://doi.org/10.1093/wber/6.suppl_1.63

Song, S. (n.d.). African Undersea Cables. Many Possibilities. Retrieved April 1, 2013, from http://manypossibilities.net/2008/02/african-undersea-cables/

Wang, E. H. (1999). ICT and economic development in Taiwan: analysis of the evidence. Telecommunication policy, 23, 235-243. https://doi.org/10.1016/s0308-5961(99)00005-1

World Bank. (1998). World Development Report 1998/99: Knowledge for Development. World Bank and Oxford University Press. https://doi.org/10.1596/978-0-1952-1118-4

\section{Copyright Disclaimer}

Copyright for this article is retained by the author(s), with first publication rights granted to the journal.

This is an open-access article distributed under the terms and conditions of the Creative Commons Attribution license (http://creativecommons.org/licenses/by/3.0/). 